\title{
Discourses and Differences: Situating Pro-Palestine Activism in Discursive Context
}

\author{
Emily Regan Wills ${ }^{1}$
}

This paper asks whether the notion of framing is sufficient to explain the ideational differences among different activist groups within a social movement. Using the example of two most prominent Arab-led pro-Palestine activist groups in New York City, Adalah-NY and AlAwda, I argue that the notion of framing obscures much of the diversity within social movements, which has effects for how analysts can understand groups' actions and successes. Instead, I argue for attention to the discursive context in which groups situate themselves, particularly the way the identities of their members and networks allow them to make arguments that can be interpreted in a variety of discursive contexts. [Article copies available for a fee from The Transformative Studies Institute. E-mail address: journal@transformativestudies.org Website: http://www.transformativestudies.org (C2016 by The Transformative Studies Institute. All rights reserved.]

KEYWORDS: Pro-Palestine Activism, Anti-War Movements, ArabAmerican Organizations, Discourse, Framing, Social Movement Theory.

Activism on behalf of Palestinians, carried out by diaspora Arabs and non-Arab residents of the United States and other Western countries, has gone almost unstudied in the literature on social movements, despite the fact that the question of Palestine and Palestinians is key in the lived experience of the well-studied contemporary peace and anti-war movements. The best explanation for this omission probably rests in the narrow range of acceptable positions in American political discourse on Israel, Palestine, and Palestinians: academics who are not personally

\footnotetext{
${ }^{1}$ Emily Regan Wills, Ph.D., is an Assistant Professor in the School of Political Studies at the University of Ottawa, where she teaches American and comparative politics. Her research focuses on transnationalism, with a focus on how Arab diaspora communities in the US build transnational relationships with the Middle East, and their engagement in politics both in their countries of origin and their countries of residence. Address correspondence to: Emily Regan Wills, University of Ottawa, School of Political Studies; e-mail: emily.wills@uottawa.ca.
} 